\title{
Питання психології
}

УДК: $355.2: 006.032$

Кримець Л.. доктор філософських наук, старший науковий співробітник, ПНС НДЛ кафедри суспільних наук НУОУ імені Івана Черняховського DOI: $10.15587 / 2313-8416.2015 .53808$

ORCID iD 0000-0001-7451-5208

\section{ЛІДЕРСТВО ЯК ОСОБЛИВА ФОРМА ВЛАДИ У СУЧАСНОМУ ВІЙСЬКОВО- ПРОФЕСІЙНОМУ СЕРЕДОВИЩІ}

\begin{abstract}
Автором визначено аксіологічний аспект феномену «влада» $у$ контексті сучасного інформачійного суспільства $і$ проведено екстраполяиію теоретичних положень у контекст військово-професійного середовища армій провідних краӥн-членів НАТО та сучасного украйнського війська через кониепт «лідерство». Запропонована стаття розкриває для читачів, що саме собою являє концепт «лідерство» за стандартами підготовки НАТО і які саме демократичні иінності складають етичну основу формування сучасного украйнського війська, що відповідатиме вимогам часу та стандартам НАТО.

Ключові слова: влада, лідерство, військово-професійне середовище, ментальність, демократичні цінності, професійна підготовка, військова освіта, соиіальна філософія.

Автором определен аксиологический аспект феномена «власть» в контексте современного информационного общества и проведена экстраполяиия теоретических положений в контекст военно-профессиональной среды армий ведущих стран НАТО и современного украинского войска через конщепт «лидерство». Предложенная статья раскрывает для читателей, что именно представляет собой кониепт «лидерство» по стандартам подготовки НАТО и какие именно демократические иенности должны составлять этическую основу формирования современного украинского войска, чтобы отвечать требованиям времени и стандартам НАТО.
\end{abstract}

Ключевые слова: власть, лидерство, военно-профессиональная среда, ментальность, демократические иенности, профессиональная подготовка, военное образование, сочиальная философия.

Влада - у сучасному розвинутому правовому суспільстві $є$ синонімом слова «відповідальність». За умови, коли суспільство формується на базі фундаментальних ліберальнодемократичних цінностей, що спрямовані на захист прав людини, впровадження соціокультурної інтегративності, забезпечення законності і відкритості системи та процесу управління, демократичного цивільного контролю над воєнною організацією та правоохоронними органами держави, принципів гендерної рівності - владою можуть бути наділені лише особи, що володіють відповідними професійними компетенціями та здатністю брати на себе величезний тягар відповідальності.

Розглядаючи теоретико-методологічні підходи до дослідження сучасного суспільства, як контексту формування владних відносин, вважаємо за доцільне звернутися до аналізу концепції постіндустріального та інформаційного суспільства. Найбільш яскравими теоретиками цього напряму $є$ Д. Белл, $\begin{array}{lcr}\text { Е. Тофлер, } & \text { Ю. Хабермас, } & \text { Н. Луман, } \\ \text { М. Маклюен. } & \text { Авторство } & \text { терміна } \\ \text { «індустріальне } & \text { суспільство» } & \text { належить }\end{array}$
Ю. Хаяші, професору Токійського технологічного інституту. В якості основної умови формування інформаційного суспільства розглядаються високотехнологічні інформаційні мережі, що досить розгалужені в глобальному світі.

У цілому, інформаційне суспільство визначається як соціум, більшість працюючих членів якого зайнята виробництвом, зберіганням, переробкою, розповсюдженням і реалізацією інформації, особливо вищої іï форми - знань. Таким чином, найважливішими стратегічними ресурсами у інформаційному суспільстві стають інформація і знання. Як писав Д. Белл: «...постіндустріальне суспільство передбачає виникнення інтелектуального класу, представники якого на політичному рівні виступають в якості консультантів, експертів або технологів». [14, с. 86]. У результаті освіта перетворилася в найважливішу соціальну цінність, сформувалися принципи меритократії, активно формується нова соціальна страта, яку можна назвати «класом інтелектуалів».

Поява такої соціальної групи була прогнозована ще в XX столітті, i iii позначили словом "меритократія". Сам цей термін був введений в обіг публікацією 


\section{Питання психології}

повісті "Піднесення меритократії" відомого британського футуролога М. Янга . Поняття меритократії (не визначене досить чітко й походить від англійського слова "merit" заслуга) містило основні риси сучасного інтелектуального класу, що увібрав в себе ряд базових характеристик наукової, підприємницької та політичної еліт суспільства.

Сучасна високопрофесійна меритократія, по-перше, орієнтована на максимальне втілення результатів своєї творчої діяльності. По-друге, вона досягає високого майнового стану, так як зосереджує велику частину власних зусиль на вирішенні прикладних задач, що дозволяють перерозподіляти на свою користь національне багатство. Потретє, представники меритократичного класу не позбавлені марнославства, що вимагає певного соціального визнання їхніх заслуг i набуття ними високо статусних суспільних посад. Саме ця соціальна група домінуе сьогодні в постіндустріальних суспільствах розвинених країн, забезпечуючи той динамізм, який притаманний останніми десятиліттями західному світові. Цей динамізм не породжений необхідністю задовольнити зовнішній виклик або внутрішні суперечності постіндустріального суспільства. Він обумовлений розкріпаченням потенціалу творчої особистості, і в цьому ми вбачаємо запоруку того, що постіндустріальний тип розвитку не може бути зупинено або змінено його напрям.

Однією 3 головних проблем $\mathrm{XXI}$ століття стане підтримка певного балансу між стрімким науковим прогресом i збереженням соціальної стабільності як у національному, так і в глобальному масштабі. Це завдання $\epsilon$ винятково складним, тому що його рішення неминуче призведе до обмеження панування меритократичної ідеології, що забезпечувала більшість успіхів, досягнутих цивілізацією протягом минулого століття. Чи зможе людство вирішити це завдання або ж виявиться втягненим в соціальні та міжнародні конфлікти 3 малопередбачуваним наслідками? питання, що вимагає першочергового та позитивного вирішення.

У військовій сфері суть проблемної ситуації складає занепад класичних форм ведення війни, необхідність осмислення та розв'язання якої передбачає звернення до філософських засад воєнної науки, оновлення освітніх стандартів підготовки військових фахівців. Завдання, які постають перед військовою теорією і практикою у зв'язку 3 трансформаціями як суспільнополітичної ситуації в Україні, так і збройної боротьби у світі, мають концептуальну природу, оскільки їхнє вирішення передбачає зміну самих способів мислення $\mathrm{i}$ дій в межах воєнної політики та військової справи.

Окремо слід зазначити, що аналіз соціально-психологічних процесів, які супроводжують хід політичних i економічних перетворень в сучасній Україні, показує, що в суспільній свідомості відбуваються перманентні трансформації в структурі ментальності, характерні для поворотних етапів історичного розвитку.

Стратегічним оборонним бюлетенем України, введеним в дію Указом Президента України від 6 червня 2016 року № 240/2016, передбачається, що професіоналізація сил оборони та створення необхідного військового резерву в Україні повинні впроваджуватись на засадах і принципах, якими керуються держави - члени НАТО. При цьому розвиток соціальногуманітарного забезпечення персоналу сил оборони, у першу чергу військовослужбовців, пов'язується зі змінами в ментальності (образі мислення) особового складу, яка, у свою чергу, повинна базуватися на основі європейських цінностей.

Згідно авторської концепції, ментальність військовослужбовця являє собою систему, що динамічно розвивається, в якій відбувається зрощування не тільки особистісного, а й професійного розвитку. Ментальність військовослужбовців Збройних Сил України та інших складових сил оборони, визначається як інтегративна професійно-обумовлена соціокультурна властивість, що зумовлює специфіку їх світосприйняття, образ мислення, особливості формування колективної та індивідуальної свідомості та професійної поведінки.

Ментальність особистості багато в чому залежить від домінуючих в суспільстві цінностей, що визначають мотиви іï життєдіяльності, значимість яких важко переоцінити. Ціннісна трансформація ментальності передбачає перш за все зміну ціннісних орієнтацій особистості. Сучасне суспільство надає широкі можливості для 


\section{Питання психології}

задоволення потреб, домагань та інтересів кожної людин. Тим часом, засоби досягнення мети регламентовані усталеними в суспільстві нормами поведінки, традиціями та цінностями.

Відповідно до проекту Статуту Збройних Сил України: Керівництво військовими формуваннями базується на принципах

\section{доброчесності,}

\section{відповідальності,} сдиноначальності, індивідуальної гендерної рівності, що передбачає відбір, призначення на посади та просування по службі осіб, які мають освіту, досвід i досягнення у певній сфері діяльності та забезпечує постійний розвиток потенціалу військової частини.

Принцип меритократії означає сприяння професіоналізації військового формування, створення відповідного військового резерву 3 урахуванням знань, бойового досвіду, вмінь та здобутків військовослужбовців при призначенні на керівні посади.

Принцип меритократії у Збройних Силах провідних країн світу розкривається через розвиток лідерства. Концепт «Лідерство» $є$ базовим для розуміння та сприяння професіоналізації Збройних Сил України та основою професійної підготовки військових та цивільних фахівців в арміях країн - членів НАТО. Пропонуємо ознайомитись 3 результатами проведених досліджень і виявити, як саме феномен «лідерство» та фундаментальні демократичні цінності знайшли вираження в проекті статуту Збройних Сил України, Кодексі честі "The NATO Code of Conduct" та стандартах підготовки фахівців у країнах -членах НАТО.

У Збройних Силах Сполучених Штатів Америки розвиток лідерства визначено фундаментальною стратегічною метою, досягнення якої спрямоване на розвиток професійного та особистісного потенціалу керівного складу та ефективну підготовку особового складу усіх рівнів. У 2013 році у Сполучених Штатах Америки була введена в дію Стратегія розвитку лідерства у Збройних Силах (Army Leader Development Strategy). Це фундаментальний документ, що визначає мету, принципи та напрямки формування лідерства.

«Армія США формує лідерів для нашої нації» - такими словами починається Стратегія розвитку лідерства Армії США.
«Розвиток лідерів $є$ конкурентною перевагою, якою володіє Армія, і в цьому аспекті вона не може бути заміщена технологією або замінена на високо розвинуту операційну систему чи озброєння» - йдеться далі в Стратегії, «Розвиток лідерства $є$ фундаментом нашої армії, і особливо іiі бойової підготовки. На даний час ми знаходимось поза балансом, зважаючи на виклики з якими ми зіткнулись та досвід, що ми отримали під час ведення бойових дій за останні 12 років. Ця стратегія допоможе армії знову збалансувати три основні компоненти розвитку лідерів: практичну підготовку, освіту та досвід.

Стратегія Розвитку Лідерства (ALDS) спрямована на впровадження нового бачення і керівництва щодо цілей, шляхів і засобів для розвитку лідерів (цивільних та військових) усіх рівнів, які беруть участь у плануванні, підготовці, виконанні та оцінці об'єднаних місій та наземних операцій та адекватної відповіді на виклики XXI століття» [5].

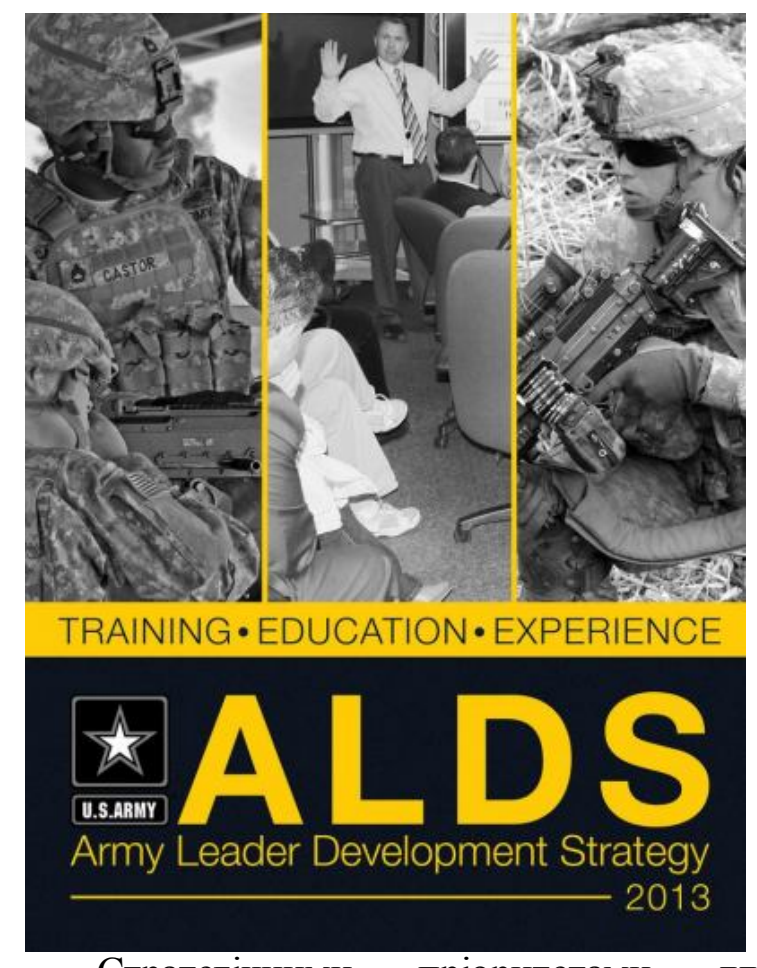

Стратегічними пріоритетами для Збройних Сил США у XXI ст. на забезпечення яких спрямована програма розвитку лідерства визначено десять головних місій, зазначених у Sustaining U.S. Global Leadership: :Priorities for $21^{\text {st }}$ Century Defense:

- захищати національні інтереси США;

- протидіяти тероризму та незаконним збройним конфліктам;

- знизити рівень агресії в світі; 


\section{Питання психології}

- нарощувати потужність, незважаючи на виклики та проблеми;

- проводити постійний облік зброї масового ураження;

- ефективно діяти в кіберпросторі і в космосі;

- забезпечити безпечне, надійне та ефективне ядерне стримування;

- захищати батьківщину та надавати підтримку цивільній владі;

- забезпечувати стабілізуючу присутність;

- проводити стабілізаційні операції та операції з придушення повстань;

- керувати наданням гуманітарної допомоги, здійснювати допомогу у ліквідації наслідків стихійних лих тощо.

«СТворюючи команди, що складаються 3 всебічно розвинених осіб, ми вдосконалюємо армію» - йдеться далі у Стратегії розвитку лідерства. Згідно означеної стратегії, talent management (управління талантами) доповнює розвиток лідерського потенціалу військовослужбовців та працівників Збройних Сил.

Керівник має враховувати індивідуальні таланти кожного офіцера та цивільного співробітника i здійснювати кадровий розподіл персоналу відповідно до знань, вмінь, особливостей поведінки та загального потенціалу, яким володіють підлеглі. В Стратегіï зазначено, що: «Армія прагне розвивати лідерів i максимально використовувати кожного військовослужбовця та цивільного працівника на основі розвитку талантів якими вони володіють, що формуються на базі практичного досвіду, шляхом розширення їх світогляду, отримання i підвищення рівня цивільної та військової освіти і задоволення їх інтересів» [5].

Для впровадження talent management y військах США існує гнучка система супроводу кар'єрних домагань кожного офіщера i цивільного співробітника, щоб військові та цивільні лідери мали можливість долучитись до здобуття якомога більш ширшого практичного досвіду та покращити власні лідерські якості в системі військової та цивільної освіти та курсової підготовки. Також в сучасній армії США реорганізовано рейтингову систему оцінки ефективності офіцера та цивільного працівника, де наразі більш ретельно оцінюються таланти людей.

Розвиток керівництва та управління талантами будуються на фундаментальних принципах. Лідери армії повинні бути живими прикладами реалізації тріади: «Будь, Знай, Дій». Військові та цивільні лідери повинні володіти і демонструвати у професійній діяльності такі риси як адаптованість, кмітливість, гнучкість, відповідальність і стійкість. Освоєння основ лідерства $€$ професійним зобов'язанням i фундаментом на якому базується професійний розвиток кожного офіцера у армії США.

Відповідно до Польового Статуту щодо розвитку лідерства у Збройних Силах США. Введеного в дію у 2015 році (Field Manual № 6-22. Leader Development. Headquaters. Departement of the Army. Washington DC, June 2015), Лідерство - це процес впливу на людей через визначення цілі, напрямку іiі досягнення та мотивацію з метою виконання поставленого завдання та покращення воєнної організації.

Військовий лідер, в силу взятої на себе відповідальності, надихає та впливає на людей, домагається досягнення поставлених цілей. Лідери мотивують людей як всередині, так і за межами військового товариства; вони спрямовують власну діяльність, мислення та приймають рішення для забезпечення якомога більш якісних результатів професійної діяльності та розвитку військової організації.

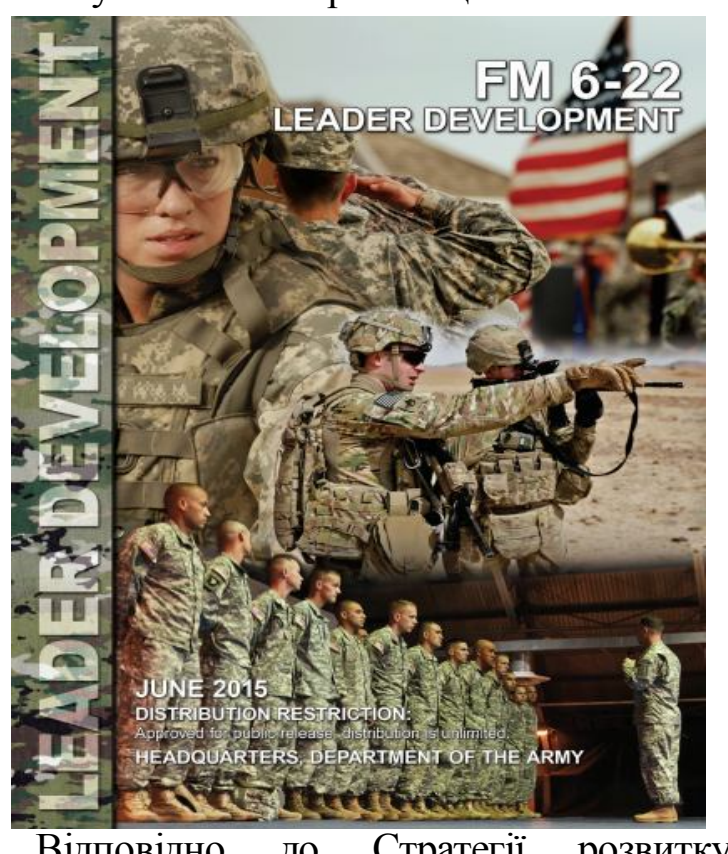

Відповідно до Стратегії розвитку лідерства (ALDS) і Польового Статуту (Field Manual № 6-22. Leader Development) розвиток лідера - це узгоджений, тривалий та цілеспрямований процес, що базується на військових цінностях та має на меті перетворити військовослужбовців та 


\section{Питання психології}

працівників Збройних Сил на компетентних впевнених лідерів, здатних на рішучі дії. Розвиток лідера досягається через постійний синтез практичної підготовки, освіти і досвіду, здобутих у процесі професійної підготовки та навчання в освітніх установах (Institutional Domain), під час участі в операціях (Operational Domain) та процесі саморозвитку (Self-development Domain) [6].

Відповідно до Польового Статуту Сухопутних військ армії США, нація та армія сформулювали очікування до розвитку лідерського потенціалу військовослужбовців усіх рівнів. Модель вимог до лідерів в армії (див. Рисунок 1) ілюструє очікування щодо розвитку лідерського потенціалу кожного керівника: військового та цивільного. Ця модель узгоджує бажаний результат діяльності 3 розвитку лідера та практики підбору персоналу 3 загальним набором характеристик, які цінують у всій армії. Він охоплює основні вимоги та очікування щодо лідерів на всіх рівнях військового управління.

Атрибути - це бажані внутрішні характеристики лідера - те, якими армія вимагає лідерів бути та те, що армія вимагає від них знати. Компетенції - це лідерські навички та поведінка, які можна сформувати та розвинути у процесі професійної підготовки. Армія очікує, що лідери володіють необхідними якостями, постійно їх демонструватимуть i продовжать вдосконалюватися. Єдність компетенцій та атрибутів призводить до довіри між лідером та підлеглими, довіри, яка грунтується на організаційному підході та ефективній роботі в команді.

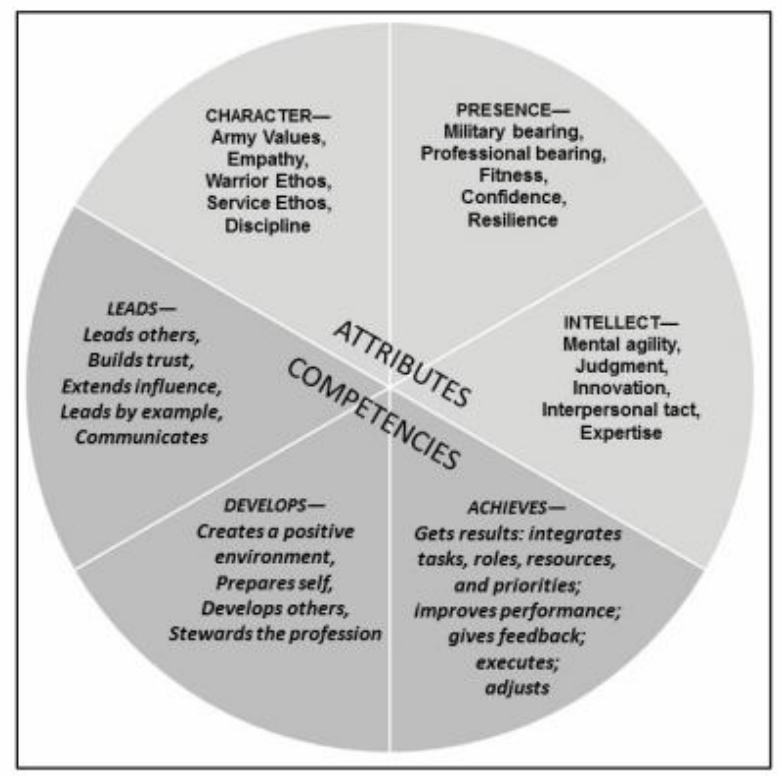

Figure 1-1. Army leadership requirements model
Лідерські атрибути включають в себе характер, зовнішні якості та інтелект військового/цивільного співробітника. Характер включає в себе прийняття базових цінностей, співпереживання (розуміння поглядів, почуттів та вірувань інших людей), військову і службову етику та дисципліну.

Базові цінності, що лежать в основі військової та службової етики окремо викладені у "The NATO Code of Conduct", Кодексі Честі військового та цивільного персоналу НАТО. Про них ми поговоримо окремо.

Зовнішній вигляд визначає враження, яке справляє лідер на оточуючих, позитивне враження допомагає йому швидше знайти прибічників для наслідування. По зовнішньому вигляду можна визначити рівень військової виучки та професійної підготовки, фізичну форму, на скільки він $\epsilon$ впевненим в собі та стійкою до зовнішніх впливів.

Інтелект впливає на те, наскільки вдало лідер вирішує завдання, знаходить вихід із складних ситуацій. Він поєднує в собі розумові здібності, здатність до обгрунтованих суджень, критичне та інноваційне мислення та вміння підтримувати продуктивну міжособистісну взаємодію.

Лідерські компетентності - це комплекс професійних вимог, що висуваються до військового/цивільного лідера 3 боку керівництва. Вони поєднують в собі здатність вести за собою, здатність до розвитку та досягнення цілей.

Компетенція «Вести за собою» містить в собі п'ять складових: направляти особовий склад, встановлювати довіру (важлива умова для створення позитивного середовища), поширювати власний вплив на підлеглих, бути прикладом для наслідування та підтримувати ефективну комунікацію.

Компетенція «Здатність до розвитку» розкривається через створення позитивного середовища, самопідготовку та самовдосконалення, розвиток підлеглого персоналу та сприяння ї професійному зростанню.

«Досягнення цілей» - це компетенція, що спрямована на досягнення визначених результатів і стосується дій, що виконуються 3 метою вчасного та якісного виконання завдання або місії. Досягнення 


\section{Питання психології}

цілі - це по суті, мета лідерства, воно забезпечується завдяки визначенню пріоритетів, інтегративному поєднанню чіткої постановки завдань, делегування повноважень, забезпечення необхідними ресурсами, підвищення ефективності роботи, забезпечення зворотного зв'язку, виконавській майстерності та вчасному реагуванню.

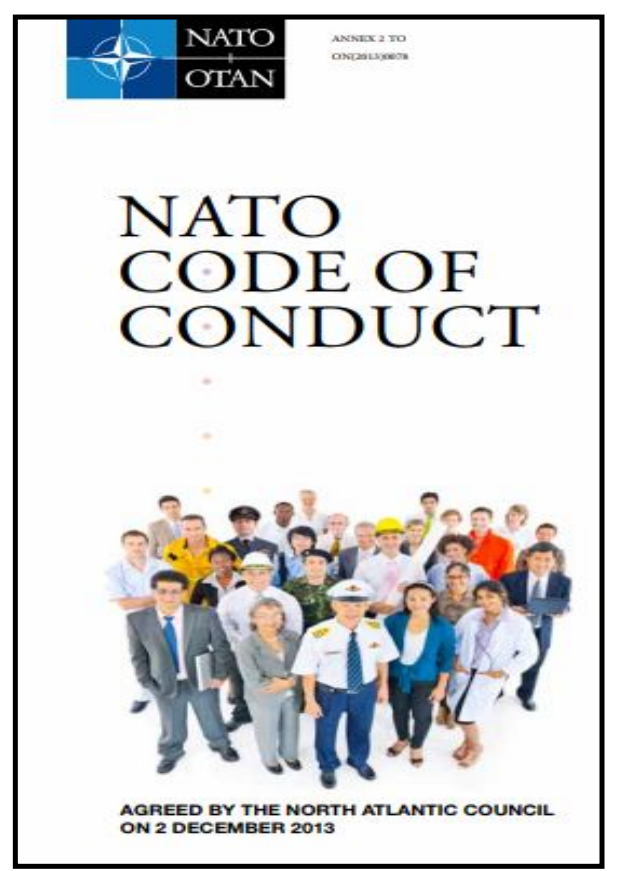

Основним міжнародним документом, що визначає базові демократичні цінності сучасного війська, вимоги до етикоморальних характеристик особового складу армій більшості країн світу є "Тhe NATO Code of Conduct". У кодексі "The NATO Code of Conduct" зазначено, що Організація Північноатлантичного альянсу (НАТО) передбачає сприяння найвищому рівню довіри між його членами та вимагає від них єдності, вірності, відповідальності, неупередженості і професіоналізму незалежно від гендерних ознак. Ці п'ять основних цінностей складають аксіологічну основу етичного Кодексу, який визначає вимоги до поведінки всіх цивільних та військових співробітників та персоналу підрозділів НАТО.

Єдність, Вірність, Відповідальність, Неупередженість Та Професіоналізм $\epsilon$ фундаментальними демократичними цінностями, що мають складати основу ментальності сучасних військовослужбовців Збойних Сил України, бути відображені в військових статутах, тексті Військової присяги, 3 врахуванням національних особливостей та передового світового досвіду формування ментальності військовослужбовців.

Повертаючись до тези про те, що Влада - у сучасному розвинутому правовому суспільстві $є$ синонімом слова «відповідальність», зазначимо, що Збройні Сили не є виключенням. Відповідальність $\epsilon$ базовим етико-моральним атрибутом військового лідера та фундаментальною демократичною цінністю, що відображена в Кодексі честі цивільного та військового персоналу НАТО. У системі розвитку лідерства в арміях країн-членів НАТО офіцери i цивільні керівники повинні свідомо, постійно і цілеспрямовано покращувати власні лідерські компетентності, карбувати лідерські якості та сприяти розвитку військової організації. Ми зазначали, що в сучасному інформаційному суспільстві владою можуть бути наділені лише особи, що володіють відповідними професійними компетенціями та здатністю брати на себе величезний тягар відповідальності. Саме такі особистості формуються в системі розвитку лідерства, що дає підстави сподіватись на формування нової військової еліти, що внесе свій внесок у вирішення сучасних та майбутніх викликів та загроз 3 якими стикається i буде стикатися людство у XXI столітті.

В якості висновку слід зазначити, що Україна $є$ молодою демократичною правовою державою, народ якої продемонстрував свою активну громадську позицію на хвилі національного піднесення. В умовах надскладних викликів сучасності стало очевидним, що роль армії як гаранта державної безпеки, як запоруки сталого розвитку суспільства, надзвичайно велика. Наша країна платить непомірно високу ціну за зниження уваги до армії в останні десятиріччя та прагне покращити якість підготовки до свідомого та відданого захисту держави нового покоління військовослужбовців, відповідальність яких перед країною, перед кожним громадянином нашої держави незмінно зростає.

Сучасне українське суспільство висуває комплекс професійних і морально-етичних вимог як до окремих військовослужбовців, так і до системи військово-професійної підготовки в цілому. У цьому зв'язку виникає потреба підготовки якісно нових керівних кадрів для органів військового управління, штабів, структур 3 морально- 


\section{Питання психології}

психологічного забезпечення усіх рівнів 3 метою впровадження значного кола суспільно-політичних та військових реформ задля демократизації та оптимізації українського війська 3 урахуванням як кращого національного, так і провідного світового досвіду.
Запропонована стаття розкриває для читачів, що саме собою являє концепт «лідерство» за стандартами підготовки НАТО і які саме демократичні цінності складають етичну основу формування сучасного українського війська, що відповідатиме вимогам часу та стандартам HATO.

\section{Список використаних джерел}

1. Белл Д. Грядущее постиндустриальное общество: Опыт социального прогнозирования [текст] / Дэниел Белл; [пер. с англ. В.Л. Иноземцева] - М.: Academia, 1999. - 788 с.

2. Кримець Л. В. Філософія влади та управління науково-освітнім простором: монографія / Людмила Володимирівна Кримець - К.: Золоті ворота, 2016. - 410 с.

3. Методичний порадник щодо формування ментальності особового складу підрозділу (військової частини) Збройних Сил України на засадах європейських цінностей / під заг. ред. Л. В. Кримець. - К.: НУОУ, 2018. -20 с.

4. Саух П. Ю. Сучасна освіта : портрет без прикрас : монографія / П. Ю. Саух. - Житомир : Видво ЖДУ ім. І. Франка, 2012. - 382 с.

5. Army Leader Development Strategy [електронний ресурс]. - Режим доступу: http://data.cape.army.mil/web/character-development-project/repository/alds-2013.pdf.

5. NATO Code of Conduct [електронний pecypc]. - Режим доступу: https://www.nato.int/structur/recruit/info-doc/code-of-conduct.pdf.

6. Field Manual № 6-22. Leader Development. Headquaters. Departement of the Army. Washington DC, June 2015.

\section{References}

1. Bell D. Hriadushchee postyndustryalnoe obshchestvo: Opyt sotsyalnoho prohnozyrovanyia [tekst] / Dэnyel Bell; [per. s anhl. V.L. Ynozemtseva]- M.: Academia, 1999. - 788 s.

2. Krymets L. V. Filosofiia vlady ta upravlinnia naukovo-osvitnim prostorom: monohrafiia / Liudmyla Volodymyrivna Krymets - K.: Zoloti vorota, 2016. - $410 \mathrm{~s}$.

3. Metodychnyi poradnyk shchodo formuvannia mentalnosti osobovoho skladu pidrozdilu (viiskovoi chastyny) Zbroinykh Syl Ukrainy na zasadakh yevropeiskykh tsinnostei / pid zah. red. L. V. Krymets. - K.: NUOU, 2018. - $20 \mathrm{~s}$.

4. Army Leader Development Strategy [electronnyi resurs]. - Rezhim dostupu: http://data.cape.army.mil/web/character-development-project/repository/alds-2013.pdf.

5. NATO Code of Conduct [electronnyi resurs]. - Rezhim dostupu: https://www.nato.int/structur/recruit/info-doc/code-of-conduct.pdf.

6. Field Manual № 6-22. Leader Development. Headquaters. Departement of the Army. Washington DC, June 2015.

\section{SUMMARY}

Liudmyla Krymets, Doctor of Science in Philosophy

\section{LEADERSHIP AS A SPECIAL FORM OF POWER IN THE MODERN MILITARY} PROFESSIONAL ENVIRONMENT

The author defined the axiological aspect of the phenomenon of "power" in the context of the modern information society and extrapolated the theoretical positions into the context of the military-professional environment of the armies of the leading NATO member states and the modern Ukrainian army through the concept of "leadership".

The goal of the article is definition of valuable aspects of power in the modern society and the modern military professional environment./

Methodologically, the author proceeds from the position of the sociocultural approach that the change in external conditions and environment inevitably entails changes (positive or negative) of the inner world of the individual, personal formations, that is, a change in the motivational and value sphere of the personality under the influence of socio-cultural factors leads to a transformation of mentality. 


\section{Питання психології}

The power - in the modern developed legal community is synonymous with the word "responsibility", the Armed Forces are no exception. Responsibility is the basic ethical and moral attribute of a military leader and fundamental democratic value as reflected in the NATO Code of Conduct. Leader Development programs in the armed forces of NATO member countries, require officers and civilian leaders improve their own leadership competences, their knowingly, continuously and purposefully, mold leadership and promote the development of a military organization.

Mentality of servicemen of the Armed Forces of Ukraine and other components of the defense forces is defined by the author as an integrative professionally conditioned socio-cultural quality that determines the specificity of their worldview, the way of thinking, the peculiarities of the formation of collective and individual consciousness and professional behavior.

In the article it is stated that in the modern information society, only individuals with the appropriate professional competences and the ability to assume a huge burden of responsibility can be given power. It is these individuals who are formed in the system of leadership development, which gives grounds to hope for the formation of a new military elite that will contribute to solving the present and future challenges and threats faced and encountered by humanity in the 21st century.

The proposed article reveals to readers what exactly is the concept of "leadership" on the standards of NATO preparation means and which democratic values constitute the ethical basis for the formation of a modern Ukrainian army that meets the requirements of time and NATO standards.

Key words: power, leadership, military-professional environment, mentality, democratic values, vocational training, military education, social philosophy. 